\title{
DO TURISMO AO PATRIMÔNIO: PERSPECTIVAS EM TRANSIÇÃO
}

Eloise Silveira Botelho

Universidade Federal do Estado do Rio de Janeiro

(UNIRIO), Rio de Janeiro, RJ, Brasil
DOI: https://doi.org/10.18472/cvt.20n1.2020.1834 Redalyc: http://www.redalyc.org/articulo.oa? id $=115462634010$

\section{Do Turismo ao PATRIMônio: PERSPECtivas EM TRANSIÇÃo}

O primeiro número do Caderno Virtual de Turismo - CVT traduz um passo em direção à fase que inauguramos em 2020. Ao longo da sua trajetória este foi um espaço ocupado majoritariamente pelo debate em torno do fenômeno do turismo e sua interface com o desenvolvimento social, oferecendo aos leitores um conteúdo pertinente e apoiado em evidente rigor científico. Dada sua contribuição à temática, apresentamos, ao final de 2019, o interesse em percorrer caminhos em convergência ao debate sobre patrimônio, e todo o campo possível de interlocução com o fenômeno turístico, conforme último editorial assinado pelo Prof. Roberto Bartholo, editor-chefe.

Nos caminhos que se abrem, não pretendemos percorrer itinerários lineares, pois isso não combina com o "espírito do CVT". Reconhecemos que o percurso constitui parte de um processo, cuja transitoriedade representa uma mudança gradual, que requer considerar no presente a bagagem adquirida ao longo, com vistas a alcançar um destino almejado.

Especialmente nesta edição, o percurso já percorrido pelo CVT tem reflexo no conteúdo apresentado pelos autores ao longo do processo de transição, em que o turismo constitui a pauta principal. Assim, oferecemos nesta edição artigos da edição ordinária e um dossiê.

A fim de contribuir para esta passagem, foram selecionados artigos que apresentam uma maior aproximação com o debate em torno do patrimônio, considerando a diversidade de abordagens possíveis. O primeiro artigo que apresentamos é "Mostra de Cinema de Tiradentes: A arquitetura efêmera como protagonista da dinâmica contemporânea", desenvolvido por Clarissa de Oliveira Neves e Maria Luiza Almeida Cunha de Castro. Neste trabalho, as autoras debatem sobre como a arquitetura efêmera, construída para atender o evento cultural, se relacionam com a cidade, com seu patrimônio construído e com a configuração de sua identidade, estimulando o turismo cultural.

Em seguida, o artigo "Imagem Técnica e Imagem Turística: considerações sobre o Instagram como motivador para o turismo", de autoria de Renan Augusto Moraes Conceição, apresenta informações sobre o uso de imagens por usuários do Instagram, e analisa como estes podem se transformar em "agências de publicidade turística ambulante”, limitando, até, o contato com a realidade do lugar visitado a uma intenção apenas econômica e comercial.

Seguindo com a perspectiva de análise sobre a constituição do mercado de turismo, os autores Taís Alexandre Antunes Paes, Rodrigo Ladeira, Maria Teresa Grimaldi Larocca, no trabalho intitulado "Destinos turísticos e a sua relação com o processo de co-criação de valor e o marketing de experiência: uma revisão bibliográfica" afirmam sobre a importância de desenvolver um planejamento de destinos capaz de integrar os setores público e privado e a comunidade local, a fim de oferecer experiências turísticas significativas.

Nesta mesma direção, o último artigo desta edição, de autoria de Alexandre Reis Rosa, Ilane Coutinho Duarte Lima e Mirelle Simões de Aguiar, analisa o processo de colaboração interorganizacional de eventos, a partir de estudo de caso "O Papel da gestão colaborativa nos festivais criativos: o caso da produção do carnaval em Vitória-ES".

Os artigos apresentados na edição ordinária do CVT somam-se ao dossiê "Experiências e reflexões sobre o projeto de inventário da oferta turística do estado do Rio de Janeiro (IOT-RJ) 2014-2019”, organizado por 
Aguinaldo Cesar Fratucci, Claudia Corrêa de Almeida Moraes e Carlos Alberto Lidizia Soares. Ancorado no tema sobre planejamento do turismo, esse dossiê é composto por artigos e relatos de experiências sobre o projeto "Inventariação da Oferta Turística nos Destinos Turísticos do Estado do Rio de Janeiro (IOT-RJ)", desenvolvido no âmbito do PRODETUR Rio de Janeiro.

Nos artigos apresentados nesta edição, o fenômeno do turismo é o foco, de modo que os leitores são convidados a realizarem uma interpretação sobre as possibilidades de vinculação com o tema do patrimônio a partir de categorias como imagem, cultura, arquitetura, experiência, e planejamento do turismo.

Assim, acreditamos que este número é um sinalizador de que novos horizontes estão abertos para e pelo Caderno Virtual de Turismo, e que as matizes revelam as nuances possíveis entre turismo e patrimônio. 